\title{
The effect of prone versus supine positioning in mortality among adult patients with moderate to severe acute respiratory distress syndrome: a meta-analysis
}

J Tabula*, LS Ordillo, PP Remalante, A Wang

From ESICM LIVES 2015

Berlin, Germany. 3-7 October 2015

\section{Introduction}

Prone positioning has been proven to increase oxygenation among patients with ARDS. However, individual RCTs did not show a significant mortality reduction among ARDS patients in prone compared to supine positioning except in the recent PROSEVA study.

\section{Objectives}

This meta-analysis assessed the effectiveness of prone versus supine positioning among patients with ARDS in reducing 28-day, 60-day, 90-day, and ICU mortality. Incidence of adverse events (ventilator-associated pneumonia, pneumothorax, endotracheal tube obstruction and unplanned endotracheal tube extubation/displacement) and length of ICU stay were also be evaluated.

\section{Methods \\ We used literature search of MEDLINE, Current Con- tents, Cochrane Central Register of Controlled Trials, Google Scholar, Science Direct, and HighWire Press to identify relevant RCTs for our meta-analysis. We used the following search strategy and $\mathrm{MeSH} /$ key terms: (prone OR prone ventilation) AND (ARDS OR acute respiratory distress syndrome). We limited our search to clinical trials. No limits are set for language of publica- tion. We performed manual search of the references from original studies and review articles to identify any additional relevant trials and increase completeness. We searched for electronic conference proceedings of the American Thoracic Society and unpublished and ongoing}

trials in ClinicalTrials.gov and Current Controlled Trials. Odds ratio with $95 \% \mathrm{CI}$ was computed for dichotomous outcomes using Mantel-Haenszel and random-effects model.

\section{Results}

Four RCTs met our inclusion criteria, including 502 patients randomized to prone ventilation and 482 patients to supine ventilation. All studies had low risk of bias. Overall, prone ventilation did not reduce 28-day $(\mathrm{OR}=$ $\left.0.64 ; 95 \% \mathrm{CI}=0.39-1.03 ; \mathrm{p}=0.05 ; I^{2}=62 \%\right), 60$-day $(\mathrm{OR}$ $=0.73 ; 95 \% \mathrm{CI}=0.44-1.23 ; \mathrm{p}=0.02 ; I^{2}=66 \%$ ), and 90-day $\left(\mathrm{OR}=0.71 ; 95 \% \mathrm{CI}=0.39-1.27 ; \mathrm{p}=0.03 ; I^{2}=73 \%\right)$ except for ICU mortality $(\mathrm{OR}=0.59 ; 95 \% \mathrm{CI}=0.38-0.92 ; \mathrm{p}=$ $0.09 ; I^{2}=58 \%$ ). Length of ICU stay was not reduced (OR $\left.=1.28 ; 95 \% \mathrm{CI}=-2.10-4.66 ; \mathrm{p}=0.34 ; I^{2}=13 \%\right)$. Prone ventilation did not increase adverse events except for endotracheal tube obstruction $(\mathrm{OR}=2.02 ; 95 \% \mathrm{CI}=$ $1.35-3.03 ; \mathrm{p}=0.88 ; I^{2}=0 \%$ ).

\section{Conclusions}

Our meta-analysis does not suggest a beneficiary effect of prone positioning on mortality (28-day, 60-day, 90-day) except for ICU mortality among overall moderate to severe ARDS patients. In addition, our data suggests that ventilation in the prone position increases the incidence of airway obstruction but does not shorten days of ICU stay nor increase incidence of ventilatorassociated pneumonia, unplanned endotracheal tube extubation/displacement, or pneumothorax. 


\section{Submit your manuscript to a SpringerOpen ${ }^{\mathcal{O}}$ journal and benefit from:}

- Convenient online submission

- Rigorous peer review

- Immediate publication on acceptance

- Open access: articles freely available online

- High visibility within the field

- Retaining the copyright to your article

Submit your next manuscript at $\gg$ springeropen.com 